\title{
Genetic factors associated with intestinal metaplasia in a high risk Singapore-Chinese population: a cohort study
} Feng Zhu' ${ }^{1}$, Marie Loh ${ }^{2}$, Jeffrey Hill ${ }^{3}$, Sumarlin Lee ${ }^{2}$, King Xin Koh², Kin Wai Lai ${ }^{2}$, Manuel Salto-Tellez ${ }^{2,4}$, Barry Iacopetta ${ }^{5}$, Khay Guan Yeoh ${ }^{1}$, Richie Soong*2,4 and the Singapore Gastric Cancer Consortium

\author{
Address: ${ }^{1}$ Department of Medicine, National University of Singapore, Singapore, Singapore, ${ }^{2}$ Cancer Science Institute of Singapore, National \\ University of Singapore, Singapore, Singapore, ${ }^{3}$ Experimental Therapeutics Centre, Agency for Science, Technology and Research (A*STAR), \\ Singapore, Singapore, ${ }^{4}$ Department of Pathology, National University of Singapore, Singapore, Singapore and ${ }^{5}$ School of Surgery, The University \\ of Western Australia, Perth, Australia \\ Email: Feng Zhu - mdczhuf@nus.edu.sg; Marie Loh - csimlcs@nus.edu.sg; Jeffrey Hill - jhill@etc.a-star.edu.sg; \\ Sumarlin Lee -sumarlins@yahoo.com; King Xin Koh - csikkx@nus.edu.sg; Kin Wai Lai - csilkw@nus.edu.sg; Manuel Salto- \\ Tellez - csimst@nus.edu.sg; Barry Iacopetta - barry.iacopetta@uwa.edu.au; Khay Guan Yeoh - mdcykg@nus.edu.sg; \\ Richie Soong* - csirs@nus.edu.sg; the Singapore Gastric Cancer Consortium - mdcykg@nus.edu.sg \\ * Corresponding author
}

Published: 13 October 2009

BMC Gastroenterology 2009, 9:76 doi:10.1 186/147/-230X-9-76
Received: 19 June 2009

Accepted: 13 October 2009

This article is available from: http://www.biomedcentral.com/I47I-230X/9/76

(c) 2009 Zhu et al; licensee BioMed Central Ltd.

This is an Open Access article distributed under the terms of the Creative Commons Attribution License (http://creativecommons.org/licenses/by/2.0), which permits unrestricted use, distribution, and reproduction in any medium, provided the original work is properly cited.

\begin{abstract}
Background: Intestinal metaplasia (IM) is an important precursor lesion in the development of gastric cancer (GC). The aim of this study was to investigate genetic factors previously linked to GC risk for their possible association with IM. A total of 18 polymorphisms in 14 candidate genes were evaluated in a Singapore-Chinese population at high risk of developing GC.
\end{abstract}

Methods: Genotype frequencies were compared between individuals presenting with $(n=128)$ or without $(n=246)$ IM by both univariate and multivariate analysis.

Results: Carriers of the NQOI 609 T allele showed an association with IM in individuals who were seropositive for Helicobacter pylori (HP+; OR $=2.6 \mathrm{I}, 95 \% \mathrm{Cl}$ : I.I8-5.80, $P=.018)$. The IL-10 $819 \mathrm{C}$ allele was also associated with IM in $\mathrm{HP}+$ individuals $(\mathrm{OR}=2.32,95 \% \mathrm{Cl}: \mathrm{I} .2 \mathrm{I}-4.43, P=0.0 \mathrm{II})$, while the PTPNII A allele was associated with IM in HP- individuals (OR $=2.5 \mathrm{I}, 95 \% \mathrm{Cl}$ : I.16-5.40, $P=$ $0.019)$, but showed an inverse association in $\mathrm{HP}+$ subjects $(\mathrm{OR}=0.46,95 \% \mathrm{Cl}: 0.2 \mathrm{I}-0.99, P=0.048)$.

Conclusion: Polymorphisms in NQOI, IL-IO and PTPN I I, in combination with HP status, could be used to identify individuals who are more likely to develop IM and therefore GC.

\section{Background}

Gastric cancer (GC) is the second leading cause of cancerrelated mortality worldwide, with more than 700,000 deaths annually[1]. The late presentation of this disease is the main reason for the high mortality and highlights the importance of early detection[2]. In Japan, mass screening programs began in the 1960's and led to a significant increase in the proportion of GC diagnosed at an early stage from $8 \%$ in $1960-1964$ to $50 \%$ in $1975-1979$. However, more cost-effective screening programs that target high risk groups are needed because of the limited resources available in many Asian countries. Positive 
assessment of Helicobacter pylori (HP) infection can help to identify high risk individuals since this is a proven risk factor for GC $[3,4]$. Various genetic factors have also been associated with an increased risk for the development of GC [5-8]. These polymorphisms could be used in conjunction with HP status and together with dietary and environmental factors to target screening programs towards individuals deemed to be at high risk.

GC is thought to arise via a multi-step pathway that involves intestinal metaplasia (IM) as a precursor lesion[9]. It has been estimated that $0.25-1.1 \%$ of IM lesions will progress to GC annually, representing an 1878-fold increased lifetime risk of developing this disease in comparison to the general population $[10,11]$. In the present study, we have investigated a panel of 18 polymorphisms in 14 candidate genes for their association with IM precursor lesions in a Singapore-Chinese population considered to be at increased risk of GC because of age greater than 50 years. These polymorphisms were chosen for study because previous research has shown them to be risk factors for GC. They included SNPs in genes involved in the immune response ( $I L-1 \beta, I L-10, P T P N 11)$ [12-14], folate metabolism (FR- $\alpha, M T H F R)[15,16]$, cell growth (EGF, HER2) [17-19], cell survival (STCH)[20], cell invasion (MMP2)[21] and DNA damage or repair (NQO1, SULT1A1, TP53, ADPRT) [22-26].

\section{Methods \\ Subjects}

Subjects were recruited from the Gastric Cancer Epidemiology and Molecular Genetics Program (GCEP). This project is a prospective cohort study aiming to enroll 4,000 Singapore-Chinese subjects aged more than 50 years from four major public hospitals in Singapore (National University Hospital, Tan Tock Seng Hospital, Singapore General Hospital, Changi General Hospital). It offers screening by endoscopy and systematic follow-up for a minimum of 5 years [27]. Chinese subjects older than 50 years of age who met the following criteria were eligible to enroll in the study: (i) symptoms of dyspepsia (ie. bloating, distension, nausea, stomach pain etc), (ii) family history of gastric cancer, or (iii) a medical condition that required them to undergo gastroscopy. They must also be able to attend all study visits assigned to them. Subjects who could not undergo gastroscopy, had a history of stomach cancer or surgery, had a disabling illness, or were unable to provide informed consent were ineligible for the study. Clinical information including demographics, medical history and family history were obtained. Informed consent was obtained from all subjects and the study was approved by the institutional review boards of all hospitals involved. Blood samples from 374 individual subjects collected between April
2004 and December 2006 were used for genotyping in the present study.

Three biopsies from the antrum, body and cardia were collected for histopathological examination during each endoscopic surveillance episode. IM was diagnosed from mucosal biopsies in three locations (antrum, body and cardia) for each subject and by consensus amongst three pathologists according to the updated Sydney System for the classification and grading of gastritis [28]. In cases where $\mathrm{H}$. pylori was identified in biopsies, eradication therapy was administered according to standard clinical guidelines. For 339/374 (91\%) individuals, the HP status was determined using the Helicoblot2.1 serology test (Genelabs Diagnostics, Singapore). In individuals where this test was not performed, the HP status was determined from histological examination of biopsies from the antrum, body and cardia, as well as from past medical history. Blood samples $(8 \mathrm{mls})$ were collected into Vacutainer CPT tubes (Becton Dickinson, Franklin Lakes, NJ) and the mononuclear cells isolated and stored at $-80^{\circ} \mathrm{C}$ prior to DNA extraction using Tri-Reagent (MRC Inc, Cincinnati, $\mathrm{OH})$.

\section{Helicoblot2.I serology test}

This serological assay uses a Western Blot nitrocellulose strip containing electrophoretically separated proteins from a bacterial lysate of an ulcer-causing type strain of $\mathrm{H}$. pylori and a recombinant antigen of $\mathrm{H}$. pylori (Genelabs Diagnostics, Singapore). When incubated with diluted serum/plasma, specific antibodies to the various antigens, if present, will bind to the H. pylori antigens on the strip. These bound antibodies appear as dark bands upon reaction with goat anti-human IgG conjugated with alkaline phosphatase and a 5-bromo-4-chloro-2-indolyl-phosphate/nitroblue tetrazolium substrate solution. In order to identify the various bands present, the strip is compared with reference strips of non-reactive (negative) and reactive (positive) controls run concurrently. Determination of H. pylori seropositivity was based on criteria recommended by the kit manufacturer. They consist of (1), $116 \mathrm{kD}$ (CagA) positive band present with one or more of the following bands: $89 \mathrm{kD}$ (VacA), $37 \mathrm{kD}, 35 \mathrm{kD}, 30 \mathrm{kD}$ (UreA) and $19.5 \mathrm{kD}$ together, or with the current infection marker, (2) the presence of any one band at $89 \mathrm{kD}$ (VacA), $37 \mathrm{kD}$ or $35 \mathrm{kD}$, with or without current infection marker, or (3) the presence of both $30 \mathrm{kD}$ and $19.5 \mathrm{kD}$ with or without current infection marker.

\section{Selection of gene polymorphism panel}

A systematic literature search in PubMed was carried out using the terms "gastric cancer" and "polymorphism". From a total of 78 candidate polymorphisms identified, 18 were found to be significantly associated with the risk 
of GC and were therefore included in the current investigation of IM.

\section{Genotyping}

Table 1 shows the PCR primers, annealing temperatures and product sizes for 17 SNPs investigated in this study by pyroseqeuncing. The 86-bp variable number of tandem repeats (VNTR) polymorphism in ILRN was genotyped using PCR followed by size analysis using gel electrophoresis. The primers and PCR conditions were the same as previously reported [29]. Polymorphisms were recorded in their most commonly used notation for easy cross-referencing. For PCR, $50 \mathrm{ng}$ DNA was amplified in a $25 \mu \mathrm{l}$ reaction containing $1 \times$ FastStart Reaction Buffer, $2 \mathrm{mM}$ magnesium chloride, $10 \mu \mathrm{M}$ deoxynucleotide mix, 500 $\mathrm{nM}$ each of the forward and reverse primers and 1 unit FastStart Taq Polymerase (Roche Diagnostics, Mannheim, Germany). PCR cycling comprised of 4 minutes at $95^{\circ} \mathrm{C}$, followed by 35 cycles of 30 seconds at $95^{\circ} \mathrm{C}, 30$ seconds at the appropriate annealing temperature and 30 seconds at $72^{\circ} \mathrm{C}$, before conclusion with 7 minutes at $72^{\circ} \mathrm{C}$.

Pyrosequencing was performed by incubating the PCR products with $3 \mu \mathrm{l}$ of streptavidin magnetic beads (Amersham Pharmacia Biotech, Uppsala, Sweden) and $1 \times$ binding buffer (10 mM Tris-HCl, $2 \mathrm{M} \mathrm{NaCl}, 1 \mathrm{mM}$ EDTA, $0.1 \%$ Tween 20) and mixing for 10 minutes at $37^{\circ} \mathrm{C}$. The product mix was then denatured by 5 seconds incubation in $0.2 \mathrm{M} \mathrm{NaOH}$ solution and washed in annealing buffer (20 $\mathrm{mM}$ Tris-acetate, $2 \mathrm{mM}$ magnesium acetate) for $10 \mathrm{sec}-$ onds. The single-stranded products were transferred to an annealing buffer containing $15 \mathrm{pmol}$ of the sequencing primer (Table 1) and incubated for 2 minutes at $80^{\circ} \mathrm{C}$ in a Hybaid Maxi 14 hybridization oven (Thermo Electron, USA). Pyrosequencing was then performed on a PSQ96MA pyrosequencer instrument (Biotage AB, Uppsala, Sweden). Samples that failed to give a genotype result after the first analysis were repeated up to two times.

Table I: PCR primers and dispensation sequences for pyrosequencing of 17 SNPs evaluated for association with IM.

\begin{tabular}{|c|c|c|c|c|c|c|}
\hline \multirow[b]{2}{*}{ Locus } & \multicolumn{4}{|c|}{ PCR } & \multicolumn{2}{|c|}{ Pyrosequencing } \\
\hline & Forward Primer & Reverse Primer & ${ }^{\circ} \mathbf{C}$ & bp & Sequencing Primer & Dispensation \\
\hline ILIO -- 1082 A/G & $\begin{array}{l}\text { CTCAATCAAAGGATCCCC } \\
\text { AGAGAC }\end{array}$ & $\begin{array}{l}\text { AGGCTGGATAGGAGGTCC } \\
\text { СТTACT }\end{array}$ & 60 & 253 & $\begin{array}{l}\text { ACACTACTAAGGCTTCT } \\
\text { TTG }\end{array}$ & cgagcagta \\
\hline ILIO -- 8I9 T/C & $\begin{array}{l}\text { GGCCAATTTAATCCAAGG } \\
\text { TTT }\end{array}$ & $\begin{array}{l}\text { TCTGCACTTGCTGAAAGC } \\
\text { TTCTTA }\end{array}$ & 60 & 207 & $\begin{array}{l}\text { CCTTGTACAGGTCATGT } \\
\text { AA }\end{array}$ & gtcgatctc \\
\hline IL-IB -- 5II T/C & $\begin{array}{l}\text { CATGAGATTGGCTAGGGT } \\
\text { AACAG }\end{array}$ & $\begin{array}{l}\text { GCCCTCCCTGTCTGTATT } \\
\text { GA }\end{array}$ & 60 & 230 & $\begin{array}{l}\text { CAATTGACAGAGAGCTC } \\
\text { C }\end{array}$ & atctgagca \\
\hline MMP2 -- 1306 T/C & $\begin{array}{l}\text { TTTCATCTCTGGGCCATT } \\
\text { GT }\end{array}$ & $\begin{array}{l}\text { TGAAGTTCTCCCTGTGAC } \\
\text { AACC }\end{array}$ & 60 & 265 & TCCCCACCCAGCACT & gctgactct \\
\hline$E G F+6 I A / G$ & $\begin{array}{l}\text { GTCATCCCTGCTTTCCTG } \\
\text { TGTG }\end{array}$ & $\begin{array}{l}\text { CAGAGCAAGGCAAAGGCT } \\
\text { TAGA }\end{array}$ & 60 & 266 & CCCAATCCAAGGGTTGT & cagactgac \\
\hline PTPNII (intl) A/G & TGGACGAATGGCAAATTG & $\begin{array}{l}\text { GATCAATCCCACCTGAGA } \\
\text { CAGA }\end{array}$ & 60 & 182 & $\begin{array}{l}\text { TTGTCTCTAAAGGACTG } \\
\text { TG }\end{array}$ & tgagctcat \\
\hline NQ0I C609T & $\begin{array}{l}\text { AACTGCATGGAATTGGTT } \\
\text { GACTTA }\end{array}$ & $\begin{array}{l}\text { TGGTGTCTCATCCCAAAT } \\
\text { ATTCT }\end{array}$ & 60 & 191 & GTGGCTTCCAAGTCTTA & cgatcgtca \\
\hline STCH rs224266I & $\begin{array}{l}\text { AACTCGAATCCTGGACCT } \\
\text { GATTAG }\end{array}$ & $\begin{array}{l}\text { CTGGCGTTTATAATCAAA } \\
\text { CCTGTG }\end{array}$ & 65 & 203 & GCGGAAAGAGAAAGG & gctagtact \\
\hline STCH rs $|88288|$ & $\begin{array}{l}\text { CTATGGAAGGCTGCGAGA } \\
\text { AC }\end{array}$ & $\begin{array}{l}\text { ACTTCCAGCTACAGGCAA } \\
\text { CATT }\end{array}$ & 65 & 213 & GAGGCTTTTTCCATCA & gcagtcgtg \\
\hline STCH rs 12479 & $\begin{array}{l}\text { CTTGAAGGACCGTGTTGA } \\
\text { TGT' }^{\prime}\end{array}$ & $\begin{array}{l}\text { GCAAAGGTCTCGGATAAC } \\
\text { AAAAA }\end{array}$ & 60 & 312 & ATGTTTCAGCACCAT & gatagctag \\
\hline STCH rs9982492 & $\begin{array}{l}\text { TCGTGCTTACCTTGTTCA } \\
\text { CATT }\end{array}$ & $\begin{array}{l}\text { AGTATGAGCCCTGCCATG } \\
\text { A }\end{array}$ & 60 & 193 & $\begin{array}{l}\text { CCACTTGTCCTTTAAGT } \\
\text { CC }\end{array}$ & actcgactc \\
\hline SULTIAI G638A & $\begin{array}{l}\text { GCCAGATCGCCTCTGAGG } \\
T\end{array}$ & $\begin{array}{l}\text { TGGGGGACGGTGGTGTA } \\
\text { GT }\end{array}$ & 65 & 233 & CCTGGAGTTTGTGGG & tgcgagctc \\
\hline ADPRT T2285C & $\begin{array}{l}\text { GATACCTAAGTCGGGGGC } \\
\text { TTTC }\end{array}$ & $\begin{array}{l}\text { ACAAGCTTTCCAGGAGAT } \\
\text { CCTAAC }\end{array}$ & 65 & 262 & TGCTCCTCCAGGCCA & cagtctgat \\
\hline HER2 + I7exI7 A/G & $\begin{array}{l}\text { GTCCCTCCCACCCCAAAC } \\
\text { TA }\end{array}$ & CTGCCGTCGCTTGATGAG & 65 & 145 & СССTCTGACGTCCAT & gtcagatct \\
\hline TP53 C2I5G & $\begin{array}{l}\text { TCCCAAGCAATGGATGAT } \\
\text { TTGA }\end{array}$ & $\begin{array}{l}\text { AAGCCCAGACGGAAACC } \\
\text { GTAG }\end{array}$ & 60 & 230 & CAGAGGCTGCTCCCC & tgcagtgct \\
\hline FR-a AI3I4G & $\begin{array}{l}\text { AAGTGGAGACTGAGGCCC } \\
\text { AGA }\end{array}$ & TGACCCCTCCCCACCAAC & 60 & 183 & GTGTGGCCTGCTCAA & cgagtacga \\
\hline MTHFR C677T & $\begin{array}{l}\text { ACTGTCATCCCTATTGGC } \\
\text { AGGTTA }\end{array}$ & $\begin{array}{l}\text { TCGGTGCATGCCTTCACA } \\
\text { A }\end{array}$ & 60 & 168 & GAAGGTGTCTGCGGG & cgagtacga \\
\hline
\end{tabular}


The genotyping success rate varied from $85-99 \%$ for the 18 polymorphisms.

\section{Statistics}

Univariate analyses were carried out by Pearson's chisquare or the Fisher's exact test to examine for associations between genotype distributions, IM status and clinical factors. As there were more than one polymorphism investigated in IL1O and STCH, the haplotypes were also considered in the analyses. Variables found significantly associated with IM in the univariate analyses for all cases, and HP+ and HP- subgroups were entered in respective multivariate logistic regression models. The analyses were based on the assumption of a dominant genetic model. All statistical analyses were performed using SPSS 16.0 (SPSS Inc., Chicago, IL) software at the 5\% significance level. The Woolf test was used to test for homogeneity of OR between two strata. As each polymorphism was tested for association with IM independently, it was not necessary to control for the family-wise error rate. Thus, no adjustment was made for multiple testing.

\section{Results}

The characteristics of 374 subjects evaluated in this study are shown in Table 2. A total of 128 were diagnosed with IM and 246 without IM. No significant differences between IM+ and IM- groups were apparent for sex, family history of GC (including $1^{\text {st }}$ degree and $2^{\text {nd }}$ degree relatives), alcohol consumption (at least one unit of wine, beer or liquor per week) or smoking status (at least one cigarette per day for a minimum of one year). IM+ subjects showed a significantly higher incidence of HP infection and were also older $(P<0.05)$.

Genotype frequencies for the 18 polymorphisms investigated for association with IM are presented in Table 3. All polymorphisms were in Hardy-Weinberg equilibrium (P

Table 2: Characteristics of study subjects in relation to the presence of IM.

\begin{tabular}{llll}
\hline & Total (\%) & IM+ (\%) & IM- (\%) \\
\hline Subjects & 374 & 128 & 246 \\
Mean age \pm SD (range) & $60.5 \pm 7.8$ & $62.9 \pm 7.8$ & $59.2 \pm 7.5$ \\
Age 50-59 yrs & $190(51)$ & $48(38)^{*}$ & $142(58)^{*}$ \\
Age 60-69 yrs & $133(36)$ & $55(43)$ & $78(32)$ \\
Age $\geq 70$ yrs & $51(13)$ & $25(19)$ & $26(10)$ \\
Male & $207(55)$ & $72(56)$ & $135(55)$ \\
Family history of GC & $66(18)$ & $23(18)$ & $43(17)$ \\
HP infection & $191(51)$ & $84(66)^{*}$ & $107(43)^{*}$ \\
Drinker & $66(18)$ & $22(17)$ & $46(19)$ \\
Smoker & $90(24)$ & $30(23)$ & $60(24)$ \\
Chronic gastritis & $290(78)$ & $115(90)$ & $175(71)$ \\
Atrophy gastritis & $194(52)$ & $97(76)$ & $97(39)$ \\
Dysplasia & $I(0.3)$ & $1(0.8)$ & 0 \\
\hline
\end{tabular}

$* p<0.05$
$>0.05$ ), with the exception of IL10 -819T/C, NQO1 609C/ $\mathrm{T}$ and TP53 Arg72Pro. By univariate analysis, the NQO1 609 T allele was the only variant in the overall cohort that was significantly associated with IM $(\mathrm{OR}=1.82,95 \% \mathrm{CI}$ : 1.05-3.15, $P=0.032$ ). In HP- individuals, only the PTPN11 rs2301756 A allele was significantly associated with IM (OR $=2.51,95 \%$ CI: $1.16-5.40, P=0.019)$. Three polymorphisms in $\mathrm{HP}+$ individuals were associated with IM in univariate analysis: the $I L-10819 \mathrm{C}$ allele $(\mathrm{OR}=$ 2.32, 95\%CI: 1.21-4.43, $P=0.011)$, NQO1 609 T allele $(\mathrm{OR}=2.61,95 \% \mathrm{CI}: 1.18-5.80, P=0.018)$ and PTPN11 A allele (OR $=0.46,95 \% \mathrm{CI}: 0.21-0.99, P=0.048)$. The haplotypes in IL10 and STCH were not significantly associated with IM in overall cohort, HP--, as well as HP+ groups.

In multivariate analysis that included all cases, HP status and age were significantly associated with IM, while the NQO1 T allele showing borderline association (Table 4). In HP- individuals, the PTPN11 A allele was the only factor associated with IM. However, in HP+ individuals the factors of older age and the NQO1 609 T allele, IL-10 819 $\mathrm{C}$ allele and PTPN11 A allele were all significantly associated with IM. These results suggest that HP status is an effect modifier of the association between IM and the PTPN11 A allele $(P=0.002)$. As it is possible that IM+/HPcases in this study had prior unrecorded HP infection[30], subgroup analysis on cases with a "revised $\mathrm{HP}+$ " status (either $\mathrm{HP}+/ \mathrm{IM}-, \mathrm{HP}+/ \mathrm{IM}+$ or $\mathrm{HP}-/ \mathrm{IM}+$ ) was also performed. Age $(\mathrm{OR}=2.10,95 \% \mathrm{CI}$ : $1.24-3.56, P=0.006)$ and $I L-10-819$ C allele (OR $=1.82,95 \% \mathrm{CI}: 1.07-3.08, P=$ 0.027 ) were the only significant variables in this subgroup.

\section{Discussion}

In this study, 18 polymorphisms that were previously linked to GC were investigated for possible associations with IM in a Singapore-Chinese population. The assumption was made that IM represents a precursor lesion for the development of GC and hence should have similar genetic risk factors. The cohort evaluated here was considered to be at elevated risk for GC because of the selection of individuals aged $>50$ years [27]. As expected, older individuals and those demonstrating seropositivity for HP showed a doubling in the frequency of IM (Table 4).

Following univariate analysis, 3 genotypes were found to be associated with IM. The NQO1 609 T allele was associated with IM, particularly in HP+ individuals. The IL-10 $819 \mathrm{C}$ allele was also significantly associated with IM in $\mathrm{HP}+$ cases. Interestingly, the PTPN11 A allele in intron 3 (rs2301756) was associated with increased incidence of IM in HP- individuals but a decreased incidence in HP+ cases. In multivariate analysis, all 3 polymorphisms remained significantly associated with IM, with the excep- 
Table 3: Distribution of genotype frequencies according to IM and HP infection status

\begin{tabular}{|c|c|c|c|c|c|c|c|}
\hline \multirow{2}{*}{$\begin{array}{l}\text { Gene polymorphism } \\
\text { (rs number) }\end{array}$} & \multirow[t]{2}{*}{ Genotype } & \multirow[t]{2}{*}{ IM- } & \multirow[t]{2}{*}{ IM+ } & \multicolumn{2}{|c|}{ HP. } & \multicolumn{2}{|c|}{ HP+ } \\
\hline & & & & IM- & IM+ & IM- & IM+ \\
\hline \multirow{3}{*}{$\begin{array}{l}\text { ADPRT Val762Ala } \\
\text { (rsII364I0) }\end{array}$} & $\mathrm{TT}$ & 71 & 31 & 33 & 9 & 38 & 22 \\
\hline & TC & 117 & 60 & 64 & 24 & 53 & 36 \\
\hline & $\mathrm{CC}$ & 33 & 16 & 13 & 6 & 20 & 10 \\
\hline \multirow{3}{*}{$\begin{array}{l}E G F+6 I A / G \\
(r s 4444903)\end{array}$} & AA & 22 & 5 & 13 & 1 & 9 & 4 \\
\hline & $A G$ & 103 & 55 & 54 & 20 & 49 & 35 \\
\hline & GG & 110 & 58 & 50 & 18 & 60 & 40 \\
\hline \multirow{3}{*}{$\begin{array}{l}\text { FR- } \alpha|3| 4 A / G \\
\text { (none) }\end{array}$} & GG & 164 & 95 & 74 & 30 & 90 & 65 \\
\hline & GA & 74 & 31 & 43 & 12 & 31 & 19 \\
\hline & $A A$ & 6 & 1 & 5 & 0 & 1 & 1 \\
\hline \multirow{3}{*}{$\begin{array}{l}\text { HER2 Ile/Val } \\
(\mathrm{rs}|80| 200)\end{array}$} & AA & 174 & 92 & 87 & 32 & 87 & 60 \\
\hline & $A G$ & 60 & 30 & 29 & 8 & 31 & 22 \\
\hline & GG & 1 & 1 & 1 & 1 & 0 & 0 \\
\hline \multirow{5}{*}{$\begin{array}{l}\text { ILIRN 86-bp VNTR } \\
\text { (none) }\end{array}$} & 44 & 212 & 101 & 112 & 33 & 100 & 68 \\
\hline & 24 & 28 & 18 & 9 & 4 & 19 & 14 \\
\hline & 34 & 1 & 2 & 0 & 2 & 1 & 0 \\
\hline & 54 & 0 & I & 0 & 0 & 0 & $\mathrm{I}$ \\
\hline & 22 & 2 & 2 & 0 & 1 & 2 & 1 \\
\hline \multirow{3}{*}{$\begin{array}{l}I L-I \beta-5 I \mid C / T \\
\text { (rs I 6944) }\end{array}$} & $\mathrm{CC}$ & 64 & 35 & 33 & 10 & 31 & 25 \\
\hline & $\mathrm{CT}$ & 119 & 62 & 63 & 21 & 56 & 41 \\
\hline & $\mathrm{TT}$ & 48 & 23 & 20 & 10 & 28 & 13 \\
\hline \multirow{3}{*}{$\begin{array}{l}\text { IL-I0 -8I9T/C } \\
\text { (rs } 180087 I)\end{array}$} & $\mathrm{TT}$ & $|3|$ & 55 & 57 & 21 & 74* & 34 \\
\hline & TC & 78 & 46 & 39 & 15 & 39 & 31 \\
\hline & $\mathrm{CC}$ & 22 & 16 & 17 & 3 & 5 & 13 \\
\hline \multirow{3}{*}{$\begin{array}{l}\text { IL-I0 - I082A/G } \\
(\mathrm{rs} \mid 800896)\end{array}$} & AA & 207 & 100 & 98 & 37 & 109 & 63 \\
\hline & $A G$ & 21 & 14 & 13 & 3 & 8 & 11 \\
\hline & GG & 2 & 0 & 2 & 0 & 0 & 0 \\
\hline \multirow{3}{*}{$\begin{array}{l}\text { MMP2 - I 306C/T } \\
\text { (rs243865) }\end{array}$} & $\mathrm{CC}$ & 178 & 79 & 85 & 28 & 93 & 51 \\
\hline & $\mathrm{CT}$ & 46 & 22 & 26 & 8 & 20 & 14 \\
\hline & $\mathrm{TT}$ & 3 & 2 & 2 & 0 & 1 & 2 \\
\hline \multirow{3}{*}{$\begin{array}{l}\text { MTHFR 667C/T } \\
(\mathrm{rs} \mid 80 \mathrm{II33})\end{array}$} & $\mathrm{CC}$ & 132 & 77 & 64 & 23 & 68 & 54 \\
\hline & $\mathrm{CT}$ & 98 & 42 & 50 & 16 & 48 & 26 \\
\hline & $\mathrm{TT}$ & 14 & 7 & 8 & 2 & 6 & 5 \\
\hline \multirow{3}{*}{$\begin{array}{l}\mathrm{NQOI} 609 \mathrm{C} / \mathrm{T} \\
(\mathrm{rs} / 800566)\end{array}$} & $\mathrm{CC}$ & $64 *$ & 21 & 27 & 10 & $37^{*}$ & I I \\
\hline & $\mathrm{CT}$ & 143 & 80 & 78 & 25 & 65 & 55 \\
\hline & $\mathrm{TT}$ & 28 & 22 & 13 & 4 & 5 & 18 \\
\hline
\end{tabular}


Table 3: Distribution of genotype frequencies according to IM and HP infection status (Continued)

\begin{tabular}{|c|c|c|c|c|c|c|c|}
\hline \multirow{3}{*}{$\begin{array}{l}\text { TP53 Arg72Pro } \\
\text { (rs 1042522) }\end{array}$} & $\mathrm{CC}$ & 45 & 16 & 22 & 7 & 23 & 9 \\
\hline & CG & 126 & 78 & 66 & 23 & 60 & 55 \\
\hline & GG & 51 & 26 & 24 & 10 & 27 & 16 \\
\hline \multirow{3}{*}{$\begin{array}{l}\text { PTPNII rs230I756 } \\
\text { (rs230I756) }\end{array}$} & GG & 175 & 85 & $92 *$ & 24 & $83 *$ & 61 \\
\hline & GA & 58 & 28 & 26 & 16 & 32 & 12 \\
\hline & AA & 4 & 2 & 0 & I & 4 & I \\
\hline \multirow{3}{*}{$\begin{array}{l}\text { STCH rs } 12479 \\
\text { (rs I 2479) }\end{array}$} & GG & 102 & 58 & 51 & 20 & 51 & 38 \\
\hline & GA & 106 & 39 & 52 & 12 & 54 & 27 \\
\hline & AA & 22 & 15 & 10 & 8 & 12 & 7 \\
\hline \multirow{3}{*}{$\begin{array}{l}\text { STCH rs I88288I } \\
(\mathrm{rs} \mid 88288 \mathrm{I})\end{array}$} & AA & 58 & 34 & 24 & 13 & 34 & 21 \\
\hline & $A C$ & 123 & 58 & 67 & 15 & 56 & 43 \\
\hline & CC & 57 & 31 & 26 & 13 & 31 & 18 \\
\hline \multirow{3}{*}{$\begin{array}{l}\text { STCH rs224266I } \\
(\mathrm{rs} 224266 \mathrm{I})\end{array}$} & AA & 69 & 31 & 34 & 12 & 35 & 19 \\
\hline & AG & 106 & 46 & 52 & 13 & 54 & 33 \\
\hline & GG & 44 & 26 & 22 & 13 & 22 & 13 \\
\hline \multirow{3}{*}{$\begin{array}{l}\text { STCH rs9982492 } \\
\text { (rs9982492) }\end{array}$} & CC & 85 & 45 & 41 & 15 & 44 & 30 \\
\hline & CT & 105 & 39 & 53 & 12 & 52 & 27 \\
\hline & TT & 28 & 18 & 14 & 9 & 14 & 9 \\
\hline \multirow{3}{*}{$\begin{array}{l}\text { SULTIAI 638G/A } \\
\text { (rs928286I) }\end{array}$} & GG & 221 & 108 & 112 & 33 & 109 & 75 \\
\hline & $\mathrm{GA}$ & 16 & 10 & 6 & 6 & 10 & 4 \\
\hline & AA & 1 & 0 & I & 0 & 0 & 0 \\
\hline
\end{tabular}

* Bold type denotes significant difference in genotype frequencies

Table 4: Multivariate logistic regression analysis for associations with IM.

\begin{tabular}{lcc}
\hline & $\begin{array}{c}\text { OR for IM } \\
(\mathbf{9 5 \%} \mathbf{C I})\end{array}$ & $P$ \\
\hline All cases & & \\
HP (positive vs negative) & $2.16(1.35-3.45)$ & 0.001 \\
Age $(>60$ vs $<60$ yrs) & $2.21(1.40-3.49)$ & 0.001 \\
NQOI (CT/TT vs CC) & $1.74(0.99-3.06)$ & 0.056 \\
& & \\
HP- cases & & \\
Age $(>60$ vs $<60$ yrs $)$ & $1.92(0.92-4.00)$ & 0.082 \\
PTPNII (GA/AA vs GG) & $2.51(1.16-5.40)$ & 0.019 \\
& & \\
HP+ cases & & \\
Age $(\geq 60$ vs $<60$ yrs $)$ & $2.19(1.15-4.17)$ & 0.017 \\
NQOI (CT/TT vs CC) & $2.61(1.18-5.80)$ & 0.018 \\
IL-IO -8I9 (TC/CC vs TT) & $2.32(1.21-4.43)$ & 0.011 \\
PTPNII (GA/AA vs GG) & $0.46(0.21-0.99)$ & 0.048
\end{tabular}

tion of the NQO1 $609 \mathrm{~T}$ allele which was associated with borderline significance in the overall cohort $(P=0.056)$.

Previous data lends support to our observations. NQO1 (NAD $(\mathrm{P}) \mathrm{H}$ : quinine oxidoreductase 1) codes for $\mathrm{a}$ cytosolic enzyme that protects cells from oxidative damage by preventing the generation of semiquinone free radicals and reactive oxygen species[31]. The $\mathrm{C}$ to $\mathrm{T}$ substitution at nucleotide 609 in exon 6 results in a change of amino acid from Pro to Ser at codon 187[32]. Whereas the CC homozygous wildtype genotype (Pro/ Pro) has full enzymatic activity, the TT genotype (Ser/Ser) completely lacks activity. The NQO1 609 TT genotype has been associated with an increased risk for various tumour types including gastrointestinal and urological cancers [33-36]. An increased risk of GC in patients with a family history of upper gastrointestinal cancers was also reported for the NQO1 609 TT genotype in a study on Chinese subjects[22]. Our observation of increased prevalence of IM in carriers of the NQO1 $609 \mathrm{~T}$ allele concurs with earlier reports on its association with various cancers and can be explained by a decreased activity for the detoxification of environmental and dietary carcinogens. 
The NQO1 C609T polymorphism was previously associated with seropositivity to HP in a Japanese study[37], thus raising the possibility that it is an indirect risk factor for IM via association with HP infection. However, we found no association between the NQO1 C609T polymorphism and HP infection in the present cohort (results not shown).

Carriers of the IL-10 -819 C allele express higher mucosal levels of $I L-10$ (interleukin 10) mRNA and experience colonization with more virulent HP strains[38]. Similar to NQO1 C609T, no association was observed here between the IL-10 T-819C polymorphism and HP infection. The current result showing the IL-10 -819 C allele is associated with IM is at odds with an Italian study that reported the TT genotype was associated with increased risk of IM[29] However, two studies in Chinese and German populations found no associations between IL-10 T-819C and IM[38,39].

Other common polymorphisms in the $I L-1 \beta$ and TNF- $\alpha$ cytokine genes have been proposed to influence the host response to HP and therefore the risk of developing GC[13,29,38-42]. The $I L-1 \beta$ C-511T and $I L-10$ A-1082G polymorphisms were investigated in this cohort, but no significant associations were found with seropositivity to HP or with the presence of IM (Table 3). Previous studies reported the IL-1 $\beta-511 \mathrm{~T}$ allele increased the risk of IM in some[38,39], but not all populations[12]. One study found an association between the IL-10 A-1082G polymorphism and IM[12,43], but 3 other studies did $\operatorname{not}[12,29,39]$.

PTPN11 (protein tyrosine phosphatase, non-receptor type 11) encodes for SHP-2, a protein tyrosine phosphatase thought to play a key role in intracellular signaling elicited by growth factors and cytokines[44]. Interactions between the HP cagA protein and SHP-2 in gastric epithelial cells are believed to contribute to the development of GC[45] The PTPN11 AA genotype was associated with reduced risk of gastric atrophy in a Japanese population of HP seropositive individuals $[14,30]$. In those studies, the assessment of gastric atrophy was done with serology test (pepsinogen levels). The present results on IM in HP seropositive Singapore-Chinese support these earlier observations, although the number of AA genotype individuals (n $=6$ ) did not allow separate evaluation of this group. The diagnosis of IM was based on histology examination. The PTPN11 intron 3 G/A SNP may be in linkage disequilibrium with a coding marker that influences the interaction of SHP-2 with cagA and subsequent downstream signaling. However, its association with increased frequency of IM in HP negative individuals suggests it may play a role independently of this factor.

\section{Conclusion}

In summary, we found 3 polymorphisms associated with IM in a Singapore-Chinese population that was at high risk for GC because of older age and seropositivity for HP. The value of these SNPs in facilitating more cost-effective surveillance programs awaits further validation in large, independent cohorts.

\section{Competing interests}

The authors declare that they have no competing interests.

\section{Authors' contributions}

FZ participated in the design of the study and its coordination, performed the statistical analysis and drafted the manuscript. ML performed the literature review/statistical analysis and drafted the manuscript. JH, KWL, MST and KGY provided clinical and biological insights for the study. SL and KXK carried out the genotyping of the samples. BI drafted the manuscript. RS participated in its design and coordination, supervised the study and drafted the manuscript. All authors read and approved the final manuscript.

\section{Acknowledgements}

This work was funded in part by the National Medical Research Council of Singapore (NMRC/TCR/00I-NUS/2007), Biomedical Research Council of Singapore (BMRC 04/1/2I/19/3/2) and the Singapore Cancer Syndicate (SCS\#BU5I, SCS\#GN0I5). The authors would like to thank contributors from the Singapore Gastric Cancer Consortium that include Khek Yu HO, Yoshiaki ITO, Christopher JL KHOR, Andrea RAJNAKOVA, Kwong Ming FOCK, Choon Jin OOI, Chung King CHIA, Wee Chian LIM, Wai Keong WONG, Andrew WONG, Ming TEH, Nilesh SHAH, Robert HEWITT, Bow HO, Kee Seng CHIA, Yoon Pin LIM, Jimmy JB SO, Lynette PHAY.

\section{References}

I. Parkin DM, Bray F, Ferlay J, Pisani P: Global cancer statistics. CA Cancer J Clin 2005, 55(2):74- 108.

2. Allum WH, Powell DJ, McConkey CC, Fielding JW: Gastric cancer: a 25-year review. Br J Surg 1989, 76(6):535-540.

3. Shikata K, Doi Y, Yonemoto K, Arima H, Ninomiya T, Kubo M, Tanizaki Y, Matsumoto T, lida M, Kiyohara Y: Population-based prospective study of the combined influence of cigarette smoking and Helicobacter pylori infection on gastric cancer incidence: the Hisayama Study. Am J Epidemiol 2008, I 68(12): |409-1415.

4. Sugiyama T: Development of gastric cancer associated with Helicobacter pylori infection. Cancer Chemother Pharmacol 2004, 54(SuppI I):SI 2-20.

5. Farinati F, Cardin R, Cassaro M, Bortolami M, Nitti D, Tieppo C, Zaninotto G, Rugge M: Helicobacter pylori, inflammation, oxidative damage and gastric cancer: a morphological, biological and molecular pathway. Eur J Cancer Prev 2008, I 7(3): 195-200.

6. Tahara E: Genetic pathways of two types of gastric cancer. IARC Sci Publ 2005:327-349.

7. Kamangar F, Cheng C, Abnet CC, Rabkin CS: Interleukin-I B polymorphisms and gastric cancer risk--a meta-analysis. Cancer Epidemiol Biomarkers Prev 2006, I 5( I 0): 1920-1928.

8. Hamajima N, Naito M, Kondo T, Goto Y: Genetic factors involved in the development of Helicobacter pylori-related gastric cancer. Cancer Sci 2006, 97( I I): I I 29- I I 38.

9. Correa P: Human gastric carcinogenesis: a multistep and multifactorial process--First American Cancer Society Award Lecture on Cancer Epidemiology and Prevention. Cancer Res 1992, 52(24):6735-6740. 
10. Whiting JL, Sigurdsson A, Rowlands DC, Hallissey MT, Fielding JW: The long term results of endoscopic surveillance of premalignant gastric lesions. Gut 2002, 50(3):378-38I.

II. de Vries AC, van Grieken NC, Looman CW, Casparie MK, de Vries $E$, Meijer GA, Kuipers EJ: Gastric cancer risk in patients with premalignant gastric lesions: a nationwide cohort study in the Netherlands. Gastroenterology 2008, I34(4):945-952.

12. Con SA, Con-Wong R, Con-Chin GR, Con-Chin VG, Takeuchi H, Valerin AL, Echandi G, Mena F, Brenes F, Yasuda N, et al.: Serum pepsinogen levels, Helicobacter pylori CagA Status, and cytokine gene polymorphisms associated with gastric premalignant lesions in Costa Rica. Cancer Epidemiol Biomarkers Prev 2007, I 6( I 2):263 I-2636.

13. Wu MS, Wu CY, Chen CJ, Lin MT, Shun CT, Lin JT: Interleukin- 10 genotypes associate with the risk of gastric carcinoma in Taiwanese Chinese. Int J Cancer 2003, I 04(5):617-623.

14. Goto Y, Ando T, Yamamoto K, Tamakoshi A, El-Omar E, Goto H, Hamajima $N$ : Association between serum pepsinogens and polymorphismof PTPNII encoding SHP-2 among Helicobacter pylori seropositive Japanese. Int J Cancer 2006, I I 8(I):203-208

15. Zhang G, Zhang QY, Miao XP, Lin DX, Lu YY: Polymorphisms and mutations of the folate receptor-alpha gene and risk of gastric cancer in a Chinese population. Int J Mol Med 2005, I 5(4):627-632.

16. Graziano F, Kawakami K, Ruzzo A, Watanabe G, Santini D, Pizzagalli F, Bisonni R, Mari D, Floriani I, Catalano V, et al.: Methylenetetrahydrofolate reductase $677 \mathrm{C} / \mathrm{T}$ gene polymorphism, gastric cancer susceptibility and genomic DNA hypomethylation in an at-risk Italian population. Int J Cancer 2006, I I 8(3):628-632.

17. Hamai Y, Matsumura S, Matsusaki K, Kitadai Y, Yoshida K, Yamaguch Y, Imai K, Nakachi K, Toge T, Yasui W: A single nucleotide polymorphism in the 5' untranslated region of the EGF gene is associated with occurrence and malignant progression of gastric cancer. Pathobiology 2005, 72(3): | 33-I38.

18. Jin G, Miao R, Deng Y, Hu Z, Zhou Y, Tan Y, Wang J, Hua Z, Ding W, Wang $L$, et al:: Variant genotypes and haplotypes of the epidermal growth factor gene promoter are associated with a decreased risk of gastric cancer in a high-risk Chinese population. Cancer Sci 2007, 98(6):864-868.

19. Kuraoka K, Matsumura S, Hamai Y, Nakachi K, Imai K, Matsusaki K, Oue $\mathrm{N}$, Ito $\mathrm{R}$, Nakayama $\mathrm{H}$, Yasui $\mathrm{W}$ : A single nucleotide polymorphism in the transmembrane domain coding region of HER-2 is associated with development and malignant phenotype of gastric cancer. Int / Cancer 2003, I 07(4):593-596.

20. Aoki M, Yamamoto K, Ohyama S, Yamamura Y, Takenoshita S, Sugano K, Minamoto T, Kitajima M, Sugimura $H$, Shimada $S$, et al.: A genetic variant in the gene encoding the stress 70 protein chaperone family member STCH is associated with gastric cancer in the Japanese population. Biochem Biophys Res Commun 2005, 335(2):566-574.

21. Miao X, Yu C, Tan W, Xiong P, Liang G, Lu W, Lin D: A functional polymorphism in the matrix metalloproteinase- 2 gene promoter $(-1306 \mathrm{C} / \mathrm{T})$ is associated with risk of development but not metastasis of gastric cardia adenocarcinoma. Cancer Res 2003, 63(14):3987-3990.

22. Zhang J, Schulz WA, Li Y, Wang R, Zotz R, Wen D, Siegel D, Ross D, Gabbert HE, Sarbia M: Association of NAD(P)H: quinone oxidoreductase I (NQOI) C609T polymorphism with esophageal squamous cell carcinoma in a German Caucasian and a northern Chinese population. Carcinogenesis 2003 24(5):905-909.

23. Boccia S, Sayed-Tabatabaei FA, Persiani R, Gianfagna F, Rausei S, Arzani D, La Greca A, D'Ugo D, La Torre G, van Duijn CM, et al.: Polymorphisms in metabolic genes, their combination and interaction with tobacco smoke and alcohol consumption and risk of gastric cancer: a case-control study in an Italian population. BMC Cancer 2007, 7:206

24. Wu MT, Chen MC, Wu DC: Influences of lifestyle habits and p53 codon 72 and $\mathrm{p} 2 \mathrm{I}$ codon $3 \mathrm{I}$ polymorphisms on gastric cancer risk in Taiwan. Cancer Lett 2004, 205(I):6I-68.

25. Miao X, Zhang X, Zhang L, Guo Y, Hao B, Tan W, He F, Lin D: Adenosine diphosphate ribosyl transferase and $x$-ray repair cross-complementing I polymorphisms in gastric cardia cancer. Gastroenterology 2006, I 3 I (2):420-427.
26. Zhang Z, Miao XP, Tan W, Guo YL, Zhang XM, Lin DX: [Correlation of genetic polymorphisms in DNA repair genes ADPRT and XRCCI to risk of gastric cancer]. Ai Zheng 2006, 25(I):7-10.

27. Leung WK, Wu MS, Kakugawa Y, Kim JJ, Yeoh KG, Goh KL, Wu KC, Wu DC, Sollano J, Kachintorn U, et al.: Screening for gastric cancer in Asia: current evidence and practice. Lancet Oncol 2008, 9(3):279-287

28. Dixon MF, Genta RM, Yardley JH, Correa P: Classification and grading of gastritis. The updated Sydney System. International Workshop on the Histopathology of Gastritis, Houston 1994. Am J Surg Pathol 1996, 20(1 0): I |6I-I|8|.

29. Zambon CF, Basso D, Navaglia F, Belluco C, Falda A, Fogar P, Greco E, Gallo N, Rugge M, Di Mario F, et al.: Pro- and anti-inflammatory cytokines gene polymorphisms and Helicobacter pylor infection: interactions influence outcome. Cytokine 2005, 29(4): $|4|-\mid 52$.

30. Hishida A, Matsuo K, Goto Y, Naito M, Wakai K, Tajima K, Hamajima $\mathrm{N}$ : Associations of a PTPN I I G/A polymorphism at intron 3 with Helicobactor pylori seropositivity, gastric atrophy and gastric cancer in Japanese. BMC Gastroenterol 2009, 9:51.

31. Winski SL, Koutalos Y, Bentley DL, Ross D: Subcellular localization of NAD(P)H:quinone oxidoreductase I in human cancer cells. Cancer Res 2002, 62(5): | 420-|424.

32. Kuehl BL, Paterson JW, Peacock JW, Paterson MC, Rauth AM: Presence of a heterozygous substitution and its relationship to DT-diaphorase activity. Br J Cancer 1995, 72(3):555-56I.

33. Sarbia M, Bitzer M, Siegel D, Ross D, Schulz WA, Zotz RB, Kiel S, Geddert H, Kandemir Y, Walter A, et al.: Association between NAD(P)H: quinone oxidoreductase I (NQOI) inactivating C609T polymorphism and adenocarcinoma of the upper gastrointestinal tract. Int J Cancer 2003, I 07(3):38I-386.

34. Zhang JH, Li Y, Wang R, Geddert H, Guo W, Wen DG, Chen ZF, Wei LZ, Kuang G, He M, et al.: NQO I C609T polymorphism associated with esophageal cancer and gastric cardiac carcinoma in North China. World J Gastroenterol 2003, 9(7): I 390-1393.

35. Lafuente MJ, Casterad X, Trias M, Ascaso C, Molina R, Ballesta A Zheng S, Wiencke JK, Lafuente A: NAD(P)H:quinone oxidoreductase-dependent risk for colorectal cancer and its association with the presence of K-ras mutations in tumors. Carcinogenesis 2000, 2 I(10): 1813-1819.

36. Schulz WA, Krummeck A, Rosinger I, Eickelmann P, Neuhaus C Ebert T, Schmitz-Drager B], Sies H: Increased frequency of a nullallele for NAD(P)H: quinone oxidoreductase in patients with urological malignancies. Pharmacogenetics 1997, 7(3):235-239.

37. Goto Y, Hamajima N, Honda H, Matsuo K, Yamamoto K, Tamakoshi $A$, Ando T, Goto H: Association between Helicobacter pylori seropositivity and NAD(P)H:quinone oxidoreductase I (NQOI) C609T polymorphism observed in outpatients and health checkup examinees. Gastric Cancer 2005, 8(I): I2-I7.

38. Rad R, Dossumbekova A, Neu B, Lang R, Bauer S, Saur D, Gerhard $M$, Prinz C: Cytokine gene polymorphisms influence mucosal cytokine expression, gastric inflammation, and host specific colonisation during Helicobacter pylori infection. Gut 2004, 53(8): $1082-1089$

39. Leung WK, Chan MC, To KF, Man EP, Ng EK, Chu ES, Lau JY, Lin SR, Sung JJ: H. pylori genotypes and cytokine gene polymorphisms influence the development of gastric intestinal metaplasia in a Chinese population. Am J Gastroenterol 2006 I 0 I (4):7|4-720.

40. El-Omar EM, Carrington M, Chow WH, McColl KE, Bream JH, Young HA, Herrera J, Lissowska J, Yuan CC, Rothman N, et al.: InterleukinI polymorphisms associated with increased risk of gastric cancer. Nature 2000, 404(6776):398-402.

4I. Machado JC, Figueiredo C, Canedo P, Pharoah P, Carvalho R, Nabais S, Castro Alves C, Campos ML, Van Doorn LJ, Caldas C, et al.: A proinflammatory genetic profile increases the risk for chronic atrophic gastritis and gastric carcinoma. Gastroenterology 2003, I 25(2):364-37I.

42. El-Omar EM, Rabkin CS, Gammon MD, Vaughan TL, Risch HA, Schoenberg JB, Stanford JL, Mayne ST, Goedert J, Blot WJ, et al.: Increased risk of noncardia gastric cancer associated with proinflammatory cytokine gene polymorphisms. Gastroenterology 2003, I 24(5): I 193-I201.

43. Kato I, Canzian F, Franceschi S, Plummer M, van Doorn LJ, Lu Y, Gioia-Patricola L, Vivas J, Lopez G, Severson RK, et al.: Genetic pol- 
ymorphisms in anti-inflammatory cytokine signaling and the prevalence of gastric precancerous lesions in Venezuela. Cancer Causes Control 2006, I7(9): I I83-II9I.

44. Neel BG, Gu H, Pao L: The 'Shp'ing news: SH2 domain-containing tyrosine phosphatases in cell signaling. Trends Biochem Sci 2003, 28(6):284-293.

45. Higashi H, Tsutsumi R, Muto S, Sugiyama T, Azuma T, Asaka M, Hatakeyama M: SHP-2 tyrosine phosphatase as an intracellular target of Helicobacter pylori CagA protein. Science 2002, 295(5555):683-686.

\section{Pre-publication history}

The pre-publication history for this paper can be accessed here:

http://www.biomedcentral.com/1471-230X/9/76/pre pub

Publish with Bio Med Central and every scientist can read your work free of charge

"BioMed Central will be the most significant development for disseminating the results of biomedical research in our lifetime. "

Sir Paul Nurse, Cancer Research UK

Your research papers will be:

- available free of charge to the entire biomedical community

- peer reviewed and published immediately upon acceptance

- cited in PubMed and archived on PubMed Central

- yours - you keep the copyright

Submit your manuscript here:

http://www.biomedcentral.com/info/publishing_adv.asp 